\title{
5E-LEARNING CYCLE STRATEGY: INCREASING CONCEPTUAL UNDERSTANDING AND LEARNING MOTIVATION
}

\author{
Febrianto Putra*1, Ika Yunita Nurkholifah ${ }^{2}$, Bambang Subali ${ }^{3}$, Ani Rusilowati $^{4}$ \\ 1,2,3,4 Department of Physics Education, Post Graduate Program, Universitas Negeri Semarang, Indonesia \\ *Correspondence address: febriantoputra326@gmail.com
}

Received: July $24^{\text {th }}, 2018$. Accepted: October $19^{\text {th }}, 2018$. Published: October $28^{\text {th }}, 2018$

\begin{abstract}
E learning cycle strategy was students center oriented learning model. The learning process becomes more meaningful, which are prioritized authentic experience of students, made students become actively participating, able to critical thinking skills and creatively. The phases of the learning cycle 5E consist of engagement, exploration, explanation, elaboration, and evaluation. The purpose of the research was increased learning motivation and conceptual understanding improved by discovery learning due to the $5 E$ learning cycle strategy. The research was conducted at SMA Teuku Umar Semarang. The research has used a qualitative approach. The type of research is classroom action research (CAR). The data analysis technique used a percentage of the learning motivation and the students' understanding concept. The percentage applied discovery learning by both of the first CAR cycle is $78 \%$ and the second CAR cycle is $92 \%$. The conceptual understanding was shown better in the second CAR cycle. The effectiveness discovery learning can be interpreted from the normalized gain. The score of the normalized gain is 0.52 . The category of the normalized gain is a medium gain. Students' motivation was increased by both the first cycle is $62 \%$ and the second cycle is $82 \%$. Based on the decision of the research, it can be concluded that the $5 E$ learning cycle process can influence increased students learning motivation and students understanding the concept not only heat concept but also heat transfer concept.
\end{abstract}

(C) 2018 Physics Education, UIN Raden Intan, Lampung, Indonesia.

Keywords: conceptual understanding, learning cycle, learning motivation.

\section{INTRODUCTION}

Understanding the concept is constructing meaningful of learning message, either orally, in writing or graphics in the learning process with learning media. (Hutahaean, Harahap, \& Derlina, 2017). Physics lesson has the potential course for made developing the ability to understand the concept vehicle (Mahardika, Faizah, \& Indrawati, 2017). The conceptual understanding was included in the cognitive process consist of (1) to interpreting, (2) to point out, (3) to classify, (4) to summarize, (5) to conclude, (6) to compare, and (7) to explain (Hutahaean et al., 2017) .

The critical thinking is one of the skills that was developed. it can be seen from the ability of conceptual understanding and problem-solving. The student's ability in problem-solving is built on an understanding of a concept. (Hartono, 2013; Ulina, 2017). The identification of the ability going to be developed in the physics lesson which are (1) the ability of scientific reasoning, (2) the ability to interpret representations of science such as images, equations, mathematical, and graphs, (3) the ability of the scientific process, (4) the ability to solve problems, (5) communication skills (Ulina, 2017).

Based on the identification of some ability in learning, then conducted a preliminary study of the condition of learning in class XI SMA Teuku Umar Semarang. The method used observation of student learning activities and interviews. Observations by describing the problems experienced, which are (1) students were able to present a good level of memorization of the objectives that it receives, but in fact do not understand it; 
(2) students would not be able to connect between understanding the concept of the actualization of understanding of the concept. (3) Students have difficulty understanding the concept of physics.

Results of a preliminary study using interviews to senior high school physics teacher in class XI at SMA Teuku Umar Semarang produce a description as follows: (1). Students understand the concepts being taught but the examination is a low score, because of the mathematical skills in physics solving is a low category. (2). Students not only have the intrinsic motivation in the good category but also interested in learning physics. (3). Students should be given in the form of extrinsic motivation punishment so that students interested in practicing tasks assigned by the teacher. 4). Appropriate equipment, physics lab in physics laboratory SMA Teuku Umar Semarang in either category, but the quantity of less practical tools primarily on practical tools that are fundamental.

Problems arise when expectations do not match with reality (Sugiyono, 2017). Identify the problem by observation of the student and the teacher, the exposure of the problems that occur in the classroom. in general, there are two problems, which are (1) conceptual understanding of students was poorly, (2) active participation of students in the learning process needs to be improved. Many students learn physics have misconceptions about the lesson, even though before they starting to learn it. Students should be able to both learn and apply the physics concept in the daily. Conceptual knowledge is a critical point for the generation and selection of appropriate procedures in solving problems (Kola, 2017). Conceptual understanding allows students to transfer an explanation of the phenomenon to the different situations (Kola, 2017).

Research needs to be applied an ongoing classroom action to find a solution to the problem of improving the quality of learning (Arikunto, Suhardjono, $\&$ Supardi, 2017). Teachers should familiarize students to think critically by assigning them to experiment, to seek explanations and finding solutions the problems, and to make inquiries about the matter to be discussed in the next section to understand the concept (Hartono, 2013). The effectiveness, efficiency, and standardization of teaching that is not offset by the teacher in the learning process make learning it does not achieve maximum results. (Furoidah, Indrawati, \& Subiki, 2013). The physics course was developed learning process according to the scientific approach and interactive learning (Ramdhani, Usodo, \& Subanti, 2017).

The learning process in accordance with the rules of the scientific approach focused on the activity of students in the classroom and interactive learning so that students can actively investigating and scientific attitude in solving the problem (Pratiwi \& Supardi, 2014). Science learning strategies that develop in the 21st century has a framework that combines content knowledge, pedagogical knowledge, and knowledge of technology according to the scientific approach (Sarwi, 2016). Both professional teacher and pre-service teacher should understand and apply the approach to the learning process, academic content, pedagogical content, and evaluation/assessment, which is imbued with the essence of physics. Support and demand for innovation have a relation to the organization of learning and organizational innovation (Hsiao, Chang, \& Chen, 2014).

Several factors can affect the quality of learning innovations such as teachers, students, learning materials, facilities, learning management, student, and the learning environment (Arikunto et al., 2017). Some models were varied learning can affect the motivation of students and students' understanding of the concept, 
but in fact, nowadays most teachers still use practical guide to learning with conventional models, so that the learning motivation and understanding of the concept seen clearly the low category (Ali, 2018). Classroom action research required of the application of alternative learning models that can improve student learning activities in an effort to improve motivation and understanding of the concept. which are (1) cooperative learning, (2) inquiry learning, (3) problem-based learning, and (4) projectbased learning, and (5) learning cycle (Diani, 2015; Indrasati, Indrawati, \& Supriadi, 2014; Loibl \& Rummel, 2014; Manalu, 2017; Schalk, Edelsbrunner, Deiglmayr, Schumacher, \& Stern, 2018; Siswandi, 2015). Learning cycle 4E and $5 \mathrm{E}$ learning cycle and $7 \mathrm{E}$ learning cycle applied to improve learning achievement, problem-solving skills, and critical thinking skills in secondary school and senior high school levels (Hartono, 2013; Septiana, Harjono, \& Hikmawati, 2018; Supriyatman \& Amiruddin, 2014; Ulina, 2017; Wahyuni, Syamsu, \& Muslimin, 2013). Based on the results of previous research, the invention will be developed to measure not only learning motivation but also students' understanding of the concept. The initial hypothesis that motivation to learn has a correlation with students 'understanding of the concept, the more strength of the students' motivation will have lots of energy and enthusiasm to participate in learning activities and obtain maximum learning results actively. The learning motivation is the driving force and direction of student learning activities so that the learning achievement of learning can be achieved (Sardiman, 2012). Therefore, discovery learning with $5 \mathrm{E}$ learning cycle strategy is expected to increase students' motivation and understanding of concepts on temperature and heat material. The learning methods used which are a discussion, demonstration, and practicum.

\section{THEORETICAL FRAMEWORK Learning Cycle}

Model fun learning, student-centered and provide appropriate learning resources, one of the better model which is the Learning Cycle (LC) (Wahyuni et al., 2013). The learning cycle is a studentcentered model, the learning process becomes more meaningful because it prioritizes real experience, and formed a student becomes active, critical and creative (Wahyuni et al., 2013), The phases of learning cycle $5 \mathrm{E}$ consist of engagement, exploration, explanation, elaboration, and evaluation (Sarac, 2018). The phases of the learning cycle according to Piaget learning theory and constructivism learning theory because of learning is the development of the cognitive aspects of the learning objectives is to enhance students' understanding. The phases of the learning cycle process require good scientific literacy (Ulina, 2017),

Science literacy used to develop knowledge and understanding, to achieve individual growth up and have a positive role in the wider community (Sulisworo \& Sutadi, 2017), Use of the learning cycle provides opportunities for students to express their previous knowledge and the opportunity to refute, debate their ideas, this process results in cognitive imbalance, thus developing a higher level of thinking, and good approach to studying physics (Supriyatman \& Amiruddin, 2014),

Figure 1 shown that learning cycle is one of the learning models with a constructivist approach which initially consists of three stages: exploration, invention, and discovery. Three of these stages is being turned into five stages developed by Robert Bybee (Septiana et al., 2018), 


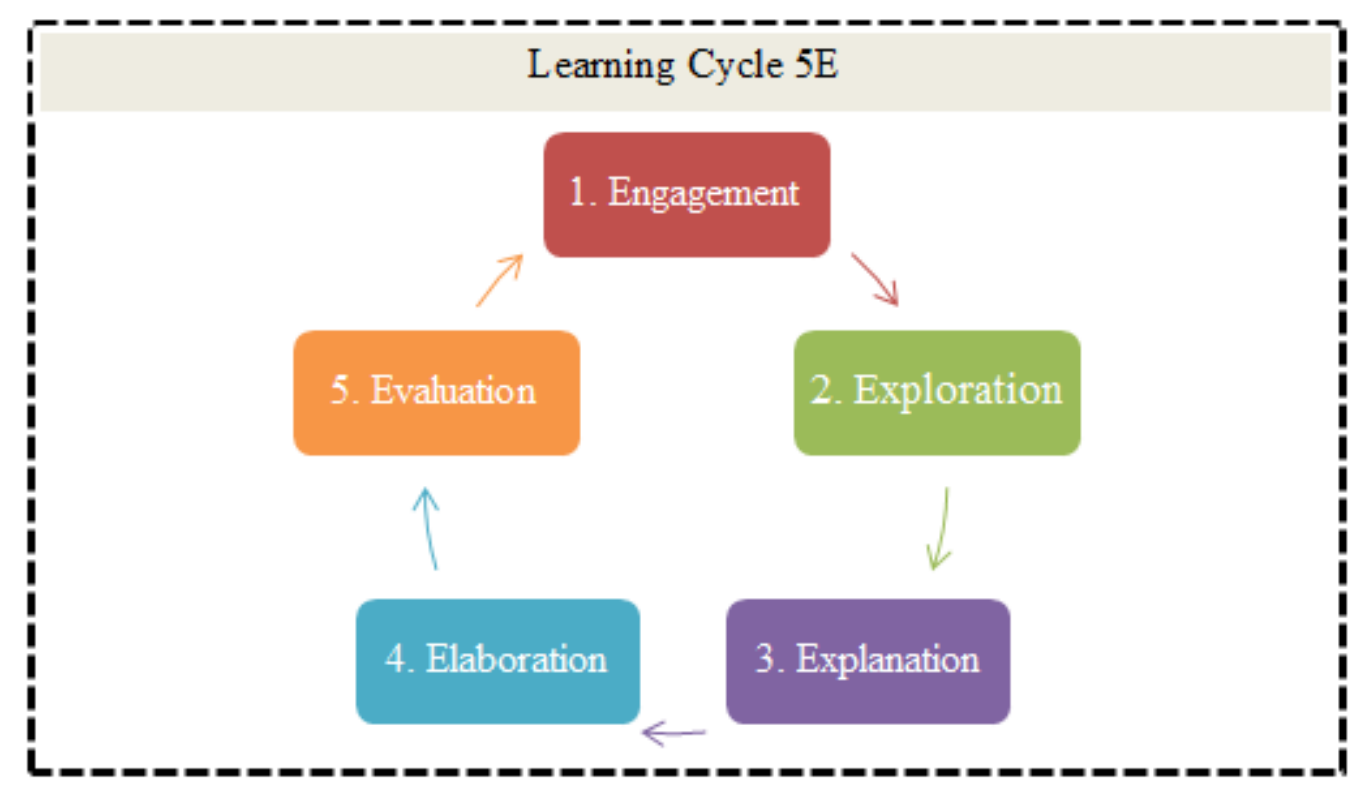

Figure 1. The phases of the $5 \mathrm{E}$ learning cycle

Learning cycle initially began as a three-phase model of the invention, the introduction of terminology and the implementation of the concept, and then expressed as 4E learning cycle consists of engagement, exploration, explanation, and extension. In subsequent years, has been developed as a model 5E learning cycle by adding additional evaluation phase by science education researchers Boddy, Watson, and Aubusson (Sarac, 2018),

The engagement phase, students enthusiastic about the lessons to be raised by providing daily physics phenomenon that corresponds to the topic and asks the students to argue about the phenomenon. Students will explore to prove their opinion about the physics phenomenon depends on the Exploration phase. The teacher presents a learning activity that gives students real experience with the concept of learning topics. Independence of the students in exploring and prove the hypothesis that they have made. The role of the teacher only as a guide and facilitator. Teacher as a facilitator in the CAR should be aware of their role in the classroom (Jan 2013),

The results were obtained from the phase of exploration, it will be explained students understand the concepts in this phase. Teacher asks profound reason to encourage students to explain what they found. Meanwhile, in the elaboration phase, students are going to build more connections between what they know with what they should have learned. In the evaluation phase, students are evaluated to assess how well students understand the concepts of the lessons. Teachers assess what students have learned in various aspects during the learning process to determine how well students understand the concepts learned. Ratings are given either orally or in writing to measure the learning process (Tania \& Murni, 2017),

\section{Discovery Learning}

Innovative learning approach had no impact in the classroom for teachers to follow the practical guidelines in teaching, those teachers can design learning and guided discovery learning using guided discovery learning heuristic learning (Janssen, Westbrook, \& van Driel, 2014), Implementation of discovery model of learning can increase students 'activity, increase understanding of the concept, and the students' critical thinking skills, as well as cognitive learning outcomes of students (Maulidar, 
Yusrizal, and Halim, 2016; Rosarina, Sudin, \& Sujana, 2016). The teacher's role as a mediator and facilitator in learning connected with learning innovations that have a relationship between an organization's learning and organizational innovation (Hsiao et al., 2014),

The role of teachers in the model of discovery learning as mentors by providing opportunities for students to learn participation actively, teachers can guide and direct the learning activities of students according to the learning objectives (Purnomo, Mujasam, \& Joseph, 2014), Conditions such as these want to change the teaching and learning activities are teacher-oriented to studentoriented.

Benefits guidance for concept discovery or invention situation has been clearly demonstrated in the teaching with discovery learning (Loibl \& Rummel, 2014), Students are placed in selfdetermined learning situations and asked to find a model or concept underlying problems. Learners need guidance during this learning activity. Table 1 shows the phases of discovery learning and $5 \mathrm{E}$ learning cycle strategy (Hartono, 2013).

Table 1 Discovery learning process and 5E learning cycle strategy

\begin{tabular}{|c|c|c|}
\hline No. & Discovery Learning & 5E Learning Cycle Strategy \\
\hline 1 & Their problems are solved. & $\begin{array}{l}\text { Teachers identify students' understanding } \\
\text { concept before the learning process. }\end{array}$ \\
\hline 2 & $\begin{array}{l}\text { The adjustment to the level of students' } \\
\text { cognitive development. }\end{array}$ & $\begin{array}{l}\text { Teachers explain the purpose of teaching and } \\
\text { learning materials needed and motivate } \\
\text { students to engage in critical thinking in } \\
\text { choosing the solution of the problems faced. }\end{array}$ \\
\hline 3 & $\begin{array}{l}\text { Concepts or principles to be found by students } \\
\text { through these activities need to be expressed } \\
\text { and written clearly. }\end{array}$ & $\begin{array}{l}\text { Teachers guide students to determine and set } \\
\text { the tasks related to the problem. }\end{array}$ \\
\hline 4 & $\begin{array}{l}\text { Must be provided the tools and the necessary } \\
\text { learning materials. }\end{array}$ & $\begin{array}{l}\text { Teachers support students to collect } \\
\text { appropriate information, conduct experiments, } \\
\text { and seek explanations and solutions to } \\
\text { problems. }\end{array}$ \\
\hline 5 & $\begin{array}{l}\text { The composition of the class is set so as to } \\
\text { facilitate the free flow of thoughts student } \\
\text { involvement in ongoing learning activities. }\end{array}$ & $\begin{array}{l}\text { Teachers guide students in designing and } \\
\text { preparing the lesson. }\end{array}$ \\
\hline 6 & $\begin{array}{l}\text { Teachers give students the opportunity to } \\
\text { collect data. }\end{array}$ & $\begin{array}{l}\text { Teachers help students to share their work } \\
\text { with their peers, evaluate and compare their } \\
\text { understanding with their prior knowledge. }\end{array}$ \\
\hline 7 & $\begin{array}{l}\text { Teachers gave the correct answer according to } \\
\text { the data and information needed by students. }\end{array}$ & $\begin{array}{l}\text { Teachers guide students to expand and reflect } \\
\text { on concepts learned }\end{array}$ \\
\hline
\end{tabular}

\section{METHOD}

The study is classroom action research (CAR). CAR process taking place in four phases consist of planning, implementation, observation, and reflection. The research experiment was conducted in two cycles. The cycle or repetition is not clearly done from planning to reflection, but only the implementation and observation phase (Arikunto et al., 2017) see Figure 2. The number of cycles depends on the outcome of reflection and learning achievement levels (see Table 5). The study was conducted in class XI IPA at SMA Teuku Umar Semarang, with a sample of 29 students of class XI. The research was conducted during four meetings with the allocation of one meeting time is a twohour lesson.

Each action consists of a series of four activities: 1) Planning, the activity of designing in detail what and how the actions to be taken. 2) The action is a core activity in the CAR, the actions of at least 
two cycles. 3) Observation is an act of gathering information that will be used to determine whether the action taken in accordance with the plan. 4) Evaluation and reflection are an activity undertaken to determine the implementation shortfall CAR (Arikunto et al., 2017). table 2 and table 3 shown the description of the activity.

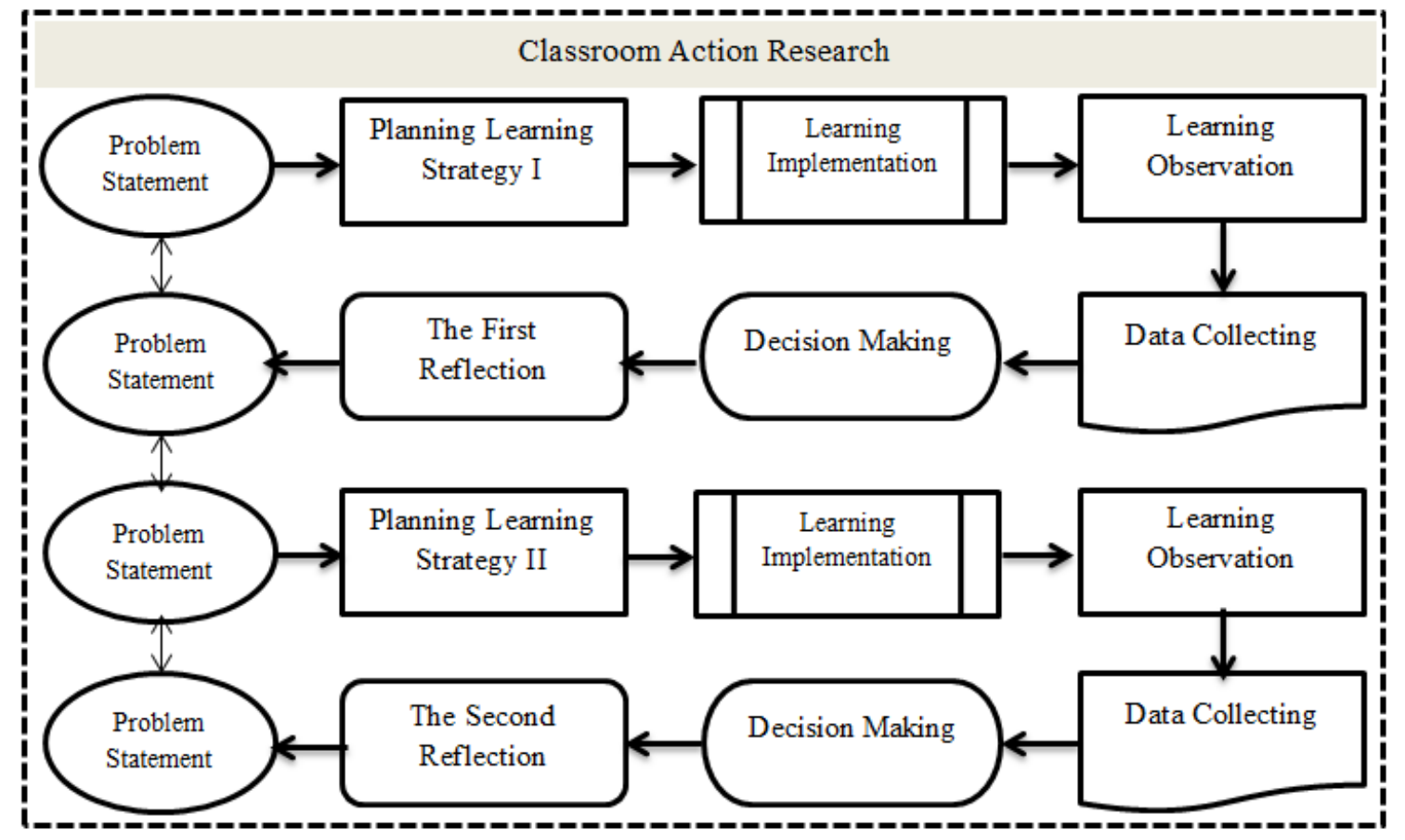

Figure 2. shown that the phases of classroom action research which are problems statement, planning learning strategy, learning implementation, learning observation, data collection, decision making, reflection, and problems statement based on the reflection learning process.

Table 2. The first cycle

Cycle Stages Description of Event

Plan $\begin{aligned} & \text { Based on the problem formulation will be applied discovery learning with } \\ & \text { demonstration method }\end{aligned}$
2. Selected topics that correspond with the content that is the temperature, heat,
and heat transfer. ( 2 meetings consist of one meeting each cycle, and will
continue with the second cycle ) selected sub-subject for the first cycle is
black rules.
3. Creating RPP (study plan) was planned for the objectives in detail exposure.
4. $\begin{aligned} & \text { Designed scenario execution of discovery learning improves in the first } \\ & \text { cycle. }\end{aligned}$
5. $\begin{aligned} & \text { Prepared physics course and instructional media will be used, as well as } \\ & \text { other documents, such as attendance, experimental tools calorimeter, student } \\ & \text { worksheets, study plan, student observation sheet, etc. }\end{aligned}$
6. Designing instruments to observe the process of learning and learning
outcomes as well as a guideline to analyze.
7. Setting up a colleague to act as an observer, and help document the activity.
1. Taught for 2 meet physics class following by the objectives about black
rules.




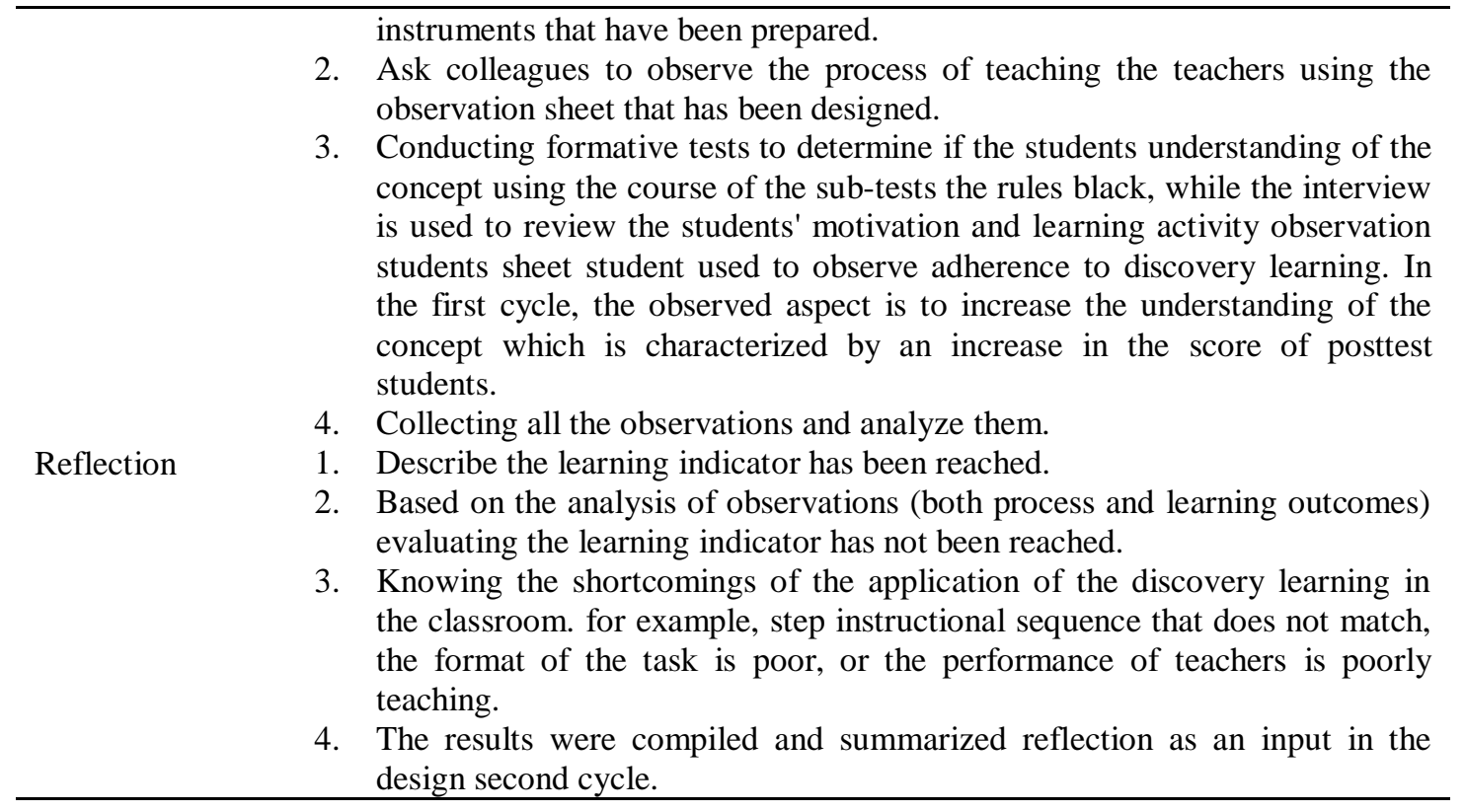

Table 3. The second cycle

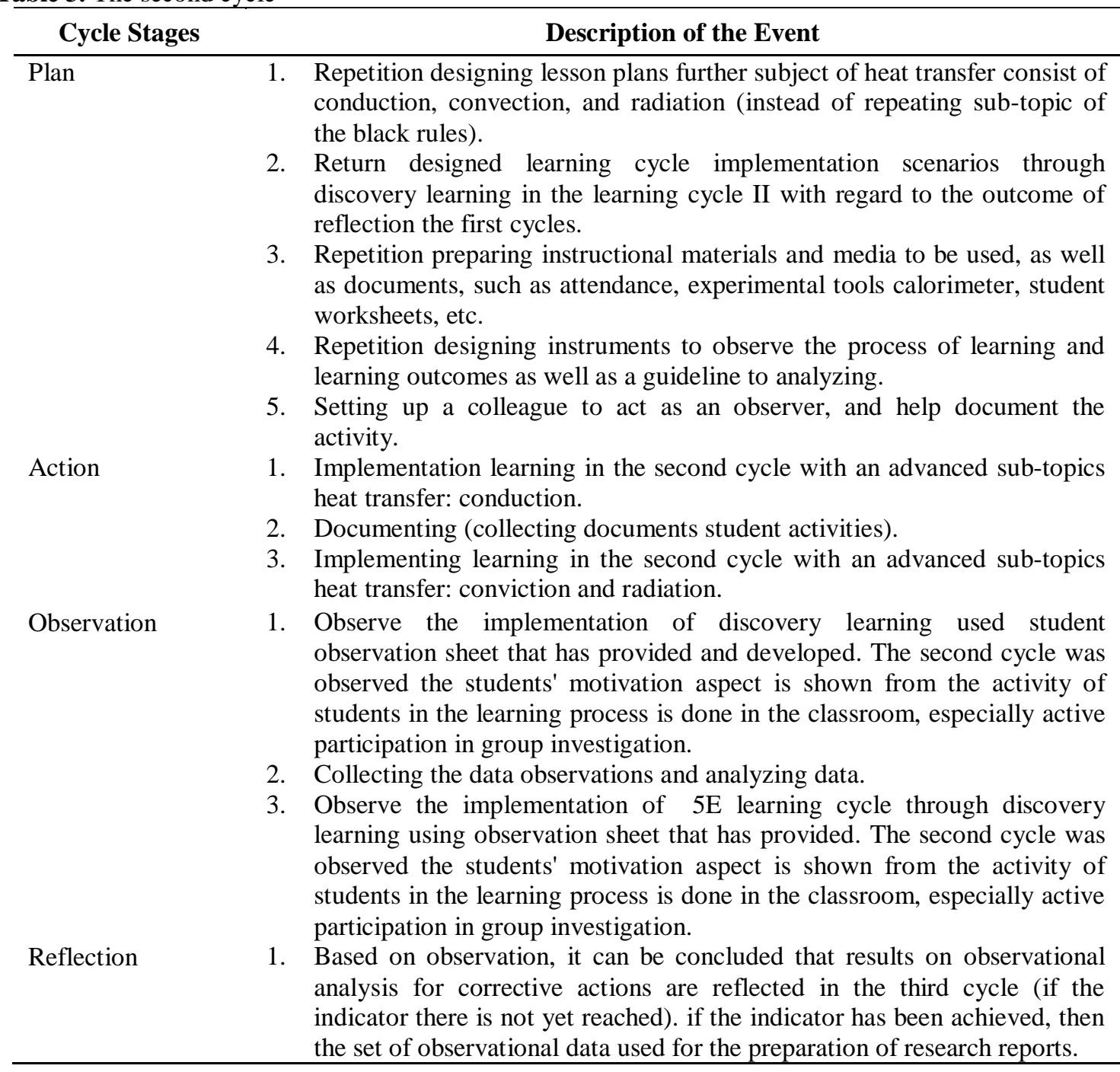




\section{RESULTS AND DISCUSSION}

Table 4 shows the results of the formative test on heat and temperature physics course. The data sample of the study was counting until 29 students. Both of the lower pre-test scores is 13, and the higher pre-test score is 66. the mean score initial condition in the first cycle is 29,3 . it is shown that poorly condition. 5E learning cycle strategy was applied as a treatment to increase the student's pre-test score. after given the treatment that can be seen clearly increase the post-test scores. Both of the lower post-test scores is 47, and the higher post-test score is 93. the mean score final condition in the second cycle is 66.2.

The percentage applied the $5 \mathrm{E}$ learning cycle which is $78 \%$ in the first cycle and $92 \%$ in the second cycle. Based on the results achieved, both values meet the implementation of indicator already predetermined. The analysis of the level of success of the classroom action research due to the 5E learning cycle strategy has increased from the first cycle until the second cycle. Improved adherence to learning is the result of reflection carried out after the first cycle to correct deficiencies occurring in the first cycle and growing up in the first cycle to apply in the next action.
The results of the students' understanding of concepts based on the cognitive process. This aspect is measured by tests conducted at the end of the cycle. furthermore, those students were made a meaning conceptual and seen either who have or who haven't completed. comparing until the end of each cycle to know that is an increase of conceptual understanding before given treatment, after the first cycle and the second cycle. The formative test results consist of both the first cycle was obtained an average score of 29.3 and the second cycle was obtained an average score of 66.2. Based on these data, it can be seen that the students' understanding of the concept increases either the first cycle or the second cycle. due to the students' understanding of physics concepts before being implemented learning cycle and thereafter learning has increased quite significantly. see table 5.

Implementation of discovery learning can improve the learning process and student achievement. Based on the results of previous studies in the first cycle, the percentage of achievement of student both the first cycle interested of $64.71 \%$ and increased in the second cycle into $82.35 \%$. Improved learning achievement is shown from the aspect of knowledge in the first cycle of $61.77 \%$ and increased in the second cycle into $85.29 \%$ (Putra, Tandililing, \& Arsyid, 2016),

Table 4. Data distribution pretest-posttest students

\begin{tabular}{ccccc}
\hline \multicolumn{2}{c}{ Data Pretest } & \multicolumn{2}{c}{ Data Posttest } & \multirow{2}{*}{ N-Gain } \\
\cline { 1 - 4 } Interval & Frequency & Interval & Frequency & \\
\hline $13-22$ & 15 & $47-55$ & 7 & \\
$23-32$ & 1 & $56-64$ & 6 & \multirow{2}{*}{0.52} \\
$33-42$ & 3 & $65-73$ & 7 & \\
$43-52$ & 6 & $74-82$ & 4 & \\
$53-62$ & 2 & $83-91$ & 1 & \\
$63-72$ & 1 & $92-100$ & 4 & \\
\hline
\end{tabular}

Based on the results of the learning process has been applied to the $5 \mathrm{E}$ learning cycle due to practical learning methods, demonstrations and discussions to increase students' activity in learning. Results of research conducted showed increased activity of students as seen from the observation of students in learning activities. The observation students' activity according to several indicators were observed consist of readiness, enthusiasm, group investigation, problemsolving, doing exercise, and decision making with reflecting (table 5 shown student activities). 
Table 5. Observations Student Activities

\begin{tabular}{clcccc}
\hline \multirow{2}{*}{ No. } & \multicolumn{1}{c}{ Rated aspect } & $\begin{array}{c}\text { Initial } \\
\text { Condition }\end{array}$ & Cycle 1 & CAR 2 & Information \\
\hline 1 & $\begin{array}{l}\text { The readiness of students to } \\
\text { receive course materials }\end{array}$ & $60 \%$ & $60 \%$ & $73 \%$ & Increased \\
2 & $\begin{array}{l}\text { The enthusiasm of students } \\
\text { in participating in group } \\
\text { discussions }\end{array}$ & $33 \%$ & $53 \%$ & $80 \%$ & Increased \\
3 & $\begin{array}{l}\text { Activities of students in } \\
\text { group discussion activities }\end{array}$ & $66 \%$ & $66 \%$ & $93 \%$ & Increased \\
4 & $\begin{array}{l}\text { Activities of students in } \\
\text { solving problems }\end{array}$ & $40 \%$ & $53 \%$ & $86 \%$ & Increased \\
5 & $\begin{array}{l}\text { Activities of students in } \\
\text { doing exercises }\end{array}$ & $53 \%$ & $73 \%$ & $73 \%$ & Increased \\
6 & $\begin{array}{l}\text { Student participation in } \\
\text { activities reflecting on } \\
\text { learning }\end{array}$ & $66 \%$ & $66 \%$ & $86 \%$ & Increased \\
\hline
\end{tabular}

\section{CONCLUSION}

Students understanding of the concept have been increased. The learning cycle type 5E conducted on class XI IPA at SMA Teuku Umar by applying for heat and temperature physics course. $5 \mathrm{E}$ learning cycle strategy consisting of the phases, which are engagement, exploration, explanation, elaboration, and evaluation. Increasing student motivation in the learning process is characterized by the improved activity of students in the learning process as measured through assessment of student activity observed during the discovery learning process takes place. Based on the decision of the research it can be concluded that the learning cycle type $5 \mathrm{E}$ process can influence increased students learning motivation and students understanding the concept.

Determining the phases of classroom action research or further studies can be reached by looking at the gap between the real condition with ideal conditions for learning. CAR going to improve the climate of the classroom in a way change their methods means or learning strategies according to the characteristics of the material to improve student achievement. Implementation the learning cycle on different types of matter physicists who have characteristics that match the learning cycle process.

\section{REFERENCES}

Ali, S. (2018). Pengaruh Model Pembelajaran dan Motivasi Belajar Fisika terhadap Hasil Belajar Fisika ( Studi Eksperimen Peserta Didik pada Kelas VIII SMP Negeri 40 Bulukumba ), 8(1), 15-28.

Arikunto, S., Suhardjono, \& Supardi. (2017). Penelitian Tindakan Kelas. (Suryani, Ed.). Jakarta: Bumi Aksara.

Diani, R. (2015). Pengembangan Perangkat Pembelajaran Fisika Berbasis Pendidikan Karakter dengan Model Problem Based Instruction. Jurnal Ilmiah Pendidikan Fisika Al-Biruni, 4(2), 241-253. https://doi.org/10.24042/jpifalbiruni. v4i2.96

Furoidah, A. Z., Indrawati, \& Subiki. (2013). Implementasi Model Discovery Learning Disertai Lembar Kerja Siswa dalam Pembelajaran Fisika Siswa di SMA. Jurnal Pembelajaran Fisika, 6(3), 285-291.

Hartono. (2013). Learning Cycle-7E Model To Increase Student ' S Critical Thinking On Science. Jurnal Pendidikan Fisika Indonesia 
(Indonesian Journal of Physics Education), 9(1), 58-66.

Hsiao, H.-C., Chang, J.-C., \& Chen, S.-C. (2014). The Influence of Support for Innovation on Organizational Innovation: Taking Organizational Learning as a Mediator. The AsiaPacific Education Researcher, 23(3), 463-472.

https://doi.org/10.1007/s40299-0130121-X

Hutahaean, R., Harahap, M. B., \& Derlina, D. (2017). The Effect of Scientific Inquiry Learning Model Using Macromedia Flash on Student's Concept Understanding and Science Process Skills in Senior High School. IOSR Journal of Research \& Method in Education (IOSRJRME), 07(04), 29-37. https://doi.org/10.9790/73880704012937

Indrasati, H., Indrawati, \& Supriadi, B. (2014). Pengaruh Model Quantum Teaching Disertai LKS Berbasis Kartun Fisika terhadap Hasil dan Motivasi Belajar Siswa dalam Pembelajaran Fisika di SMA. Jurnal Pembelajaran Fisika, 5(1), 30-35.

Jan, P. (2013). A New Scholarship of Classroom-based, Open, Communal Inquiry. Teaching and Learning Inquiry: The ISSOTL Journal, 1(1), 23-33.

https://doi.org/10.2979/teachlearninq u.1.1.23

Janssen, F. J. J. M., Westbroek, H. B., \& van Driel, J. H. (2014). How to make guided discovery learning practical for student teachers. Instructional Science, 42(1), 67-90. https://doi.org/10.1007/s11251-0139296-z

Kola, A. J. (2017). Investigating the Conceptual Understanding of Physics through an Interactive Lecture- Engagement. Cumhuyet International Journal of Education, 6(1), 82-96.
Loibl, K., \& Rummel, N. (2014). The impact of guidance during problemsolving prior to instruction on students' inventions and learning outcomes. Instructional Science, 42(3), 305-326. https://doi.org/10.1007/s11251-0139282-5

Mahardika, I. K., Faizah, M., \& Indrawati. (2017). Peningkatan Aktivitas dan Hasil Belajar Fisika Siswa pada Kelas X APK SMKN 8 Jember Tahun Ajaran 2016-2017 dengan Model Learning Cycle ( LC ) Disertai LKS Multirepresentasi. Jurnal Pembelajaran Fisika, 6(2), 126-131.

Manalu, A. (2017). Pengaruh Model Pembelajaran Kooperatif Tipe Group Investigation (GI) dengan Menggunakan Media Visual terhadap Pengetahuan Konseptual Siswa Kelas X Pada Materi Suhu dan Kalor. Jurnal Inovasi Pembelajaran Fisika, 1(1), 7-16.

Maulidar, N., Yusrizal, \& Halim, A. (2016). Pengaruh Penerapan Model Pembelajaran Guided Discovery terhadap Kemampuan Pemahaman Konsep dan Keterampilan Berpikir Kritis Siswa SMP pada Materi Kemagnetan. Jurnal Pendidikan Sanis Indonesia, 4(2), 69-75.

Pratiwi, N. W., \& Supardi, Z. A. I. (2014). Penerapan Model Pembelajaran Learning Cycle 5E pada Materi Fluida Statis Siswa Kelas X SMA. Jurnal Inovasi Pendidikan Fisika (JIPF), 03(02), 143-148.

Purnomo, H. Y., Mujasam, \& Yusuf, I. (2014). Penerapan Model Guided Discovery Learning pada Materi Kalor terhadap Hasil Belajar Kognitif Peserta Didik Kelas VII SMPN 13 Prafi Manokwari Papua Barat. Pancaran, 5(2), 1-14.

Putra, R. R., Tandililing, E., \& Arsyid, S. B. (2016). Pengaruh Model 
Discovery Learning terhadap Pemahaman Konsep Siswa Materi Getaran dan Gelombang di SMP. Jurnal Pendidikan Dan Pembelajaran, 5(10), 1-11.

Ramdhani, M. ., Usodo, B., \& Subanti, S. (2017). Discovery Learning with Scientific Approach to Geometry Discovery Learning with Scientific Approach to Geometry. Journal of Physics: Conference Series, 895(1), 0120331-0120336.

https://doi.org/10.1088/17426596/895/1/012033

Rosarina, G., Sudin, A., \& Sujana, A. (2016). Penerapan Model Discovery Learning Untuk Meningkatkan Hasil Belajar Siswa Pada Materi Perubahan Wujud Benda. Jurnal Pena Ilmiah, 1(1), 371-380.

Sarac, H. (2018). The Effect of Learning Cycle Models on Achievement of Students: A Meta-Analysis Study. International Journal of Educational Methodology, 4(1), 1-18. https://doi.org/10.12973/ijem.4.1.1

Sardiman. (2012). Interaksi dan Motivasi Belajar Mengajar. Bandung: Rajawali Pers.

Sarwi. (2016). Pembelajaran Inovatif Fisika Aktif dan Menyenangkan. Semarang: UNNES PRESS.

Schalk, L., Edelsbrunner, P. A., Deiglmayr, A., Schumacher, R., \& Stern, E. (2019). Improved application of the control-ofvariables strategy as a collateral benefit of inquiry-based physics education in elementary school. Learning and Instruction, 59(September 2018), 34-45. https://doi.org/10.1016/j.learninstruc. 2018.09.006

Septiana, I. S., Harjono, A., \& Hikmawati. (2018). Pengaruh Model Learning Cycle 5E Berbasis Eksperimen terhadap Kemampuan Berpikir Kritis Fisika Peserta Didik Kelas XI SMAN 1 Gerung. Jurnal
Pendidikan Fisika Dan Teknologi, 4(1), 7-15.

Siswandi. (2015). Peningkatan Pemahaman Konsep Kalor dengan Metode Group investigation. Jurnal Praktik Penelitian Tindakan Kelas Pendidikan Dasar Dan Menengah, 5(3), 44-49.

Sugiyono. (2017). Metode Penelitian Pendidikan Pendekatan Kuantitatif, Kualitatif, dan R\&D. Bandung: Alfa Beta.

Sulisworo, D., \& Sutadi, N. (2017). Science Learning Cycle Method to Enhance the Conceptual Understanding and the Learning Independence on Physics Learning. International Journal of Evaluation and Research in Education, 6(1), 6470.

Supriyatman, \& Amiruddin, K. (2014). Implementation of Physics Learning Material Based on the 4E Learning Cycle Method for Student SMP Negeri in Left Behind Area ( Case Study in District Parigi Moutong ). International Journal of Scientific Engineering and Research (IJSER), 2(2), 8-12.

Tania, B., \& Murni. (2017). Penerapan Model Pembelajaran learning Cycle 5e untuk Meningkatkan Pemahaman Konsep Matematika Siswa SMPN 1 Pasie Raja. Gravity: Jurnal Ilmiah Penelitian Dan Pembelajaran Fisika, 3(1), 66-79.

Ulina, N. S. (2017). Meningkatkan Keterampilan Berpikir Siswa Dengan Model Learning Cycle Dalam Pembelajaran Fisika di SMA Jakarta. Jurnal Formatif, 7(1), 49-55. Wahyuni, Z., Syamsu, \& Muslimin. (2013). Penerapan Model Learning Cycle Tipe 5E dengan Media Visual Untuk Meningkatkan Hasil Belajar Fisika Pada Siswa Kelas Xc SMA Negeri 2 Dolo. Jurnal Pendidikan Fisika Tadulako, 1(1), 1-10. 